УДК 543.573:635.112:635.48

DOI https://doi.org/10.15673/swonaft.v85i1.2069

\title{
ВПЛИВ ПАРОТЕРМІЧНОЇ ОБРОБКИ ЯБЛУК НА ТЕПЛОТУ ЗНЕВОДНЕННЯ
}

\author{
Гусарова О.В., к.т.н., Михайлик В.А., к.т.н., ст. наук. співр., Шапар Р.О., к.т.н., ст. наук. співр. \\ Інститут технічної теплофізики НАН України, м. Київ
}

\begin{abstract}
Для більш обтрунтованого виявлення можливостей інтенсифікації сушіння та глибшого розуміння процесів, які відбуваються під час зневоднення яблук, методами ТГ та ДТА було досліджено процес видалення води з них. В якості об'єктів дослідження використано свіжі та оброблені парою зразки паренхімних тканин яблук сорту Ренет Симиренко та Джонатан. Дослідження виконано в дериватографi Q-1000 в діапазоні $25 \ldots 250{ }^{\circ} \mathrm{C}$ при швидкості нагрівання 3,6 K/хв. Зневоднення яблук здійснювали методом конвективного стадійного сушіння до залишкової вологості $6 \%$ (абс).
\end{abstract}

Визначено температури максимальної швидкості зневоднення, переходу паренхімних тканин в стан, обумовлений вмістом виключно зв'язаної води та температурні інтервали термічного розкладання органічних речовин. У роботі відмічено, шьо перебіг проиесу сушіння в умовах керованого нагріву залежить від стану води. Середня швидкість видалення води з оброблених парою тканин у яблук сорту Ренет Симиренко на 14\% більша порівняно зі свіжими.

Вперше для яблук сорту Ренет Симиренко показано, щу у оброблених парою зразках через руйнування клітинних мембран відбувся перерозподіл фракційного складу води. У оброблених парою яблуках досліджених сортів зв'язаної води на 3\% менше, ніж у свіжих. Перехід зв'язаної води у вільну підтверджується значеннями середньої питомої теплоти зневоднення, яка для свіжих яблук Ренет Симиренко визначена на рівні 2630 (в діапазоні температур 25...181 C), а для оброблених парою - 2500 кДж/кг (в діапазоні температур $\left.25 \ldots 183^{\circ} \mathrm{C}\right)$. Дослідження підтверджують дочільність тепловологісної обробки паренхімних тканин сировини перед сушінням з метою інтенсифікації зневоднення та зменшення енергетичних витрат. Отримані результати можна використовувати при виборі режиму попередньої тепловологісної обробки яблук та у теплових розрахунках процесу зневоднення.

Ключові слова: дериватографія, сушіння, яблука, обробка парою, середня питома теплота зневоднення, вільна та зв’язана вода.

Вступ та постановка проблеми. Основною вимогою до технологічного процесу перероблення фруктів та овочів на сушені продукти (сухофрукти, чипси, порошки) є зниження енергетичних витрат під час зневоднення та максимальне збереження природних складових сировини. Термолабільні властивості об'єктів сушіння зумовлюють високі вимоги до температурного рівня паротермічної обробки та сушіння. Вивчення закономірностей та характеру їхніх змін залежно від інтенсивності теплового впливу дає змогу обрати й обгрунтувати найкращі режими їхнього проведення та шляхи інтенсифікації процесу.

Яблука є найпоширенішою сировиною для перероблення на сушені продукти в Україні. Їх хімічний склад (рис. 1) багатий та різноманітний. Як і більшість рослинних матеріалів яблука мають високу природну вологість $(85 . . .89 \%)$. Визначальною особливістю їх є значний вміст вуглеводів (до 16 \%), зокрема цукрів (фруктоза, глюкоза, сахароза) та пектинових речовин (протопектин, пектин, пектинова і пектова кислоти) [1, 2]. Наявність зазначених складових ускладнює процес видалення води під час сушіння.

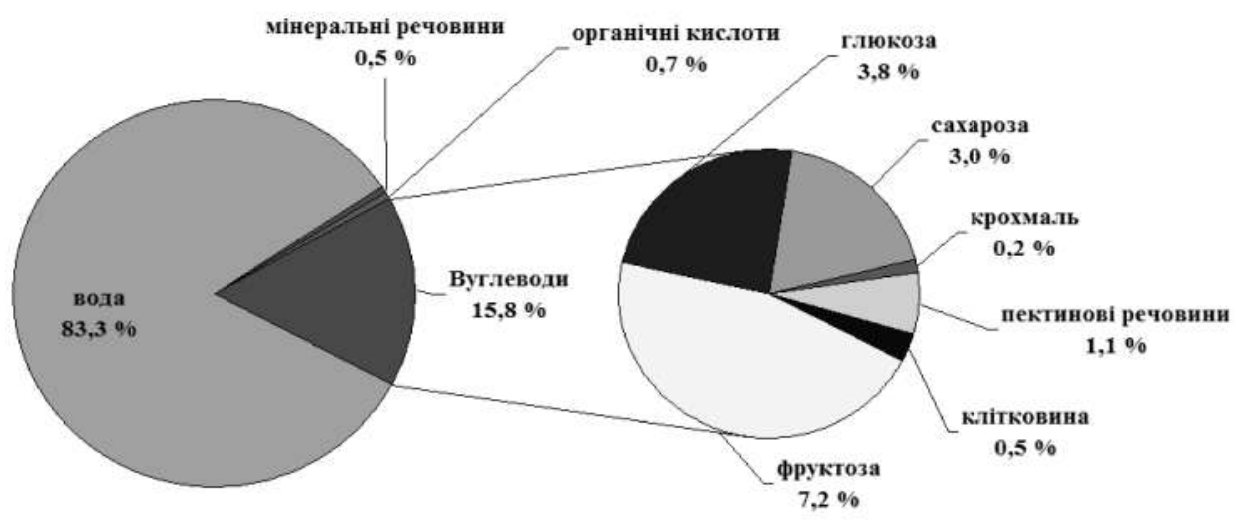

Рис. 1 - Усереднений хімічний склад яблук (у \% до загальної маси)

Для інтенсифікації процесу сушіння, зменшення енергетичних витрат та отримання належних органолептичних показників сушеного продукту проводять попередню тепловологісну обробку сировини. Під час сушіння обробленої сировини відбуваються складні процеси, яблука зазнають біологічних, фізико-хімічних 
та структурних змін, які можуть впливати на співвідношення вільної та зв'язаної води, що в свою чергу впливає на теплоту зневоднення.

У теплових розрахунках процесу сушіння фруктів, як правило, використовують взяту з довідників питому теплоту випаровування з вільної поверхні чистої води, а також дані отримані на основі аналізу кривих сорбції в області гігроскопічної вологості. Оскільки яблука є цукровмісною сировиною, а величина питомої теплоти випаровування з розчинів цукрів перевищує значення для чистої води [3], то це призводить до заниження енерговитрат при розрахунках. Відомості про зміну стану води в об'єкті сушіння під час зневоднення мають наукове значення та можуть бути використані для теплових розрахунків процесу.

Дериватографія набула широкого використання для отримання інформації про характер змін в сировині та термічну стійкість різних харчових продуктів під час зневоднення [4]. Так, наприклад, у роботі [5] досліджено зміну форм зв'язку вологи у екстракті чаю зеленого під час сушіння. Автори [6] досліджували перебіг термічного розкладання плодів лікарських рослин залежно від їх хімічного складу. Дериватографія об’єднує методи термогравіметрії (ТГ) та диференціального термічного аналізу (ДТА). Вона дозволяє сумісним аналізом кривих зміни маси (ТГ) та температури зразка (Т), швидкості зміни маси (ДТГ) та різниці температур між зразком та інертною речовиною (ДТА) якісно та кількісно оцінити процеси в сировині, що відбуваються в умовах керованого нагріву [7].

Мета та завдання дослідження. Методами термічного аналізу дослідити процес видалення води зі свіжих та оброблених парою зразків яблук для більш обгрунтованого виявлення можливостей інтенсифікації сушіння та глибшого розуміння процесів, які відбуваються під час зневоднення.

Для досягнення мети було сформульовано наступні завдання:

- дослідити форми зв'язку води в свіжих та оброблених парою паренхімних тканинах яблук;

- визначити вплив попередньої тепловологісної обробки паренхімних тканин яблук на процес сушіння та середню питому теплоту їх зневоднення.

Об'єкти та методи дослідження. В якості об'єкту дослідження використано свіжі та оброблені парою зразки паренхімних тканин яблук сорту Ренет Симиренко та Джонатан.

Дослідження виконано в дериватографі Q-1000 системи Paulik-Paulik-Erdey угорського виробництва (фірма „МОМ”) в діапазоні температур $25 \ldots 250{ }^{\circ} \mathrm{C}$ при швидкості нагрівання 3,6 К/хв. У тиглі порівняння як інертну речовину використано оксид алюмінію. Атмосферою слугувало нерухоме повітря. Корекцію шкали температур виконували по температурі плавлення бензойної кислоти. Відхилення температури під час досліджень не перевищувало $\pm 0,5$ К [7].

Свіжий або оброблений парою зразок у вигляді полого циліндру зовнішнім діаметром 6 мм і висотою 7 мм розміщували у відкритий конічний платиновий тигель. Для збору та обробки інформації було використано програмне забезпечення «Derivatograph».

Вивчення кінетики процесу сушіння свіжих та оброблених парою зразків завтовшки $\delta=3 . . .4$ мм проводили на експериментальному конвективному стенді з системою автоматичного збору та обробки інформації до залишкової вологості $W^{\mathrm{c}}=6 \%$ у режимах стадійного зневоднення за температур сушильного агента $t=80 \ldots 60{ }^{\circ} \mathrm{C}$, вологовмісту $d=10$ г/кг сухого повітря та швидкості руху $V=1,5 \mathrm{~m} / \mathrm{c}$.

Результати та їх обговорення. Дериватограми свіжих яблук сорту Ренет Симиренко та Джонатан зображено на рис. 2 та 3, оброблених парою - на рис. 4 й 5 відповідно.

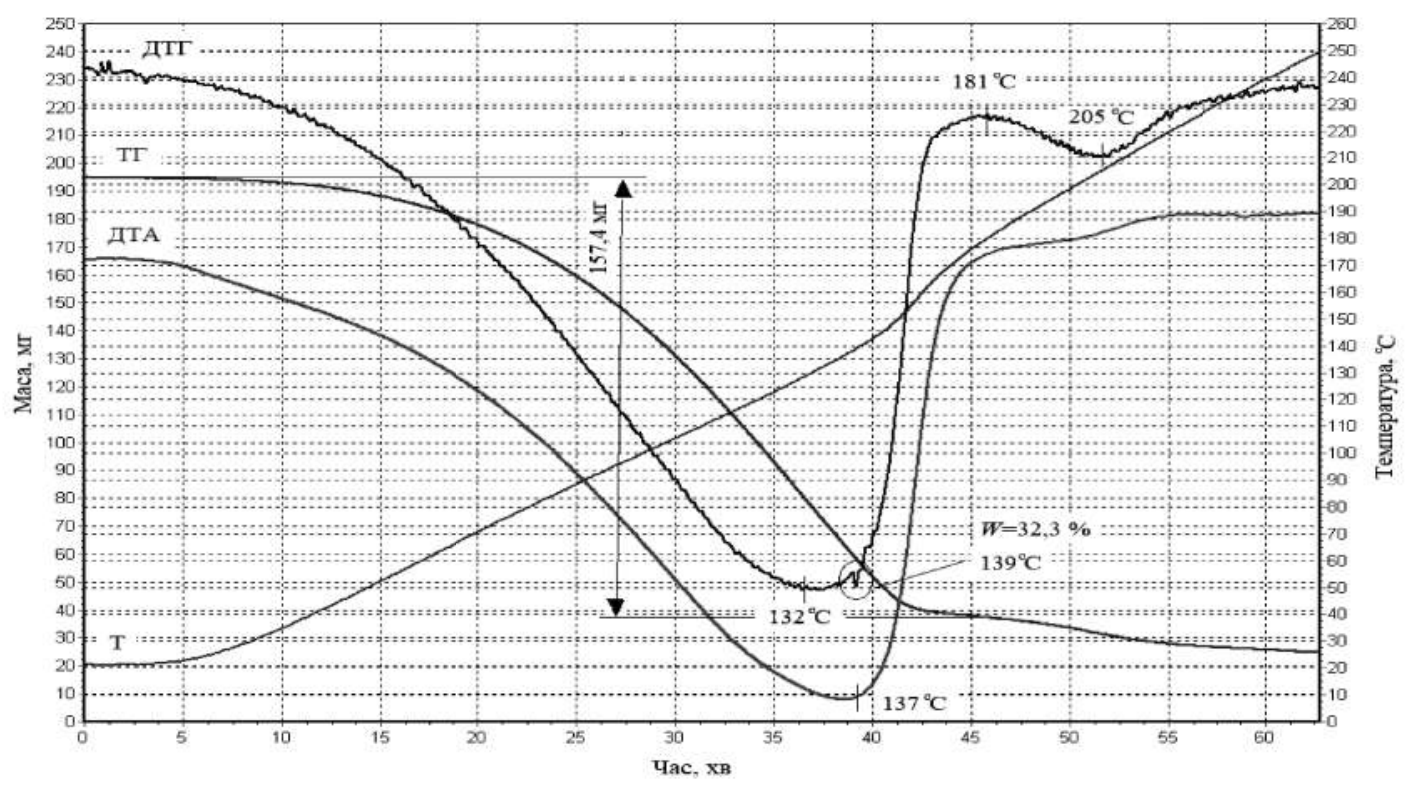

Рис. 2 - Дериватограма паренхімних тканин свіжих яблук сорту Ренет Симиренко [8] 
Із рисунків 2 та 3 видно, що видалення води у обох свіжих зразках починається при $25{ }^{\circ} \mathrm{C}$, про що свідчать криві ТГ та ДТГ. Процес іде з поглинанням теплоти, ендотермічність проявляється у відхиленні кривих ДТА до низу від уявної базової лінії. Швидкість зневоднення зразків зростає зі збільшенням їх температури і сягає максимального значення при $132{ }^{\circ} \mathrm{C}$ для яблук Ренет Симиренко і $133{ }^{\circ} \mathrm{C}$ для яблук Джонатан.

У деяких дослідженнях зроблене припущення, що температура максимуму швидкості сушіння або теплопоглинання, поділяє воду на вільну та зв'язану [5]. Проте в роботах $[9,10]$ було доведено, що це не так. Вимірювання методом диференціальної скануючої калориметрії показали, що під час зневоднення термолабільної цукровмісної сировини одночасно з випаровуванням вільної води відбувається зменшення питомого вмісту зв'язаної води. Граничний вологовміст, по досягненню якого в паренхімних тканинах яблук залишається лише зв'язана вода, був наведений в [9] і відповідає відносній вологості $W=32,3 \%$.

По точці на кривій ДТГ (рис. 2 та 3), що відповідає зазначеній вологості, можна визначити температуру (табл. 1), після досягнення якої в зразках залишається тільки зв'язана вода.

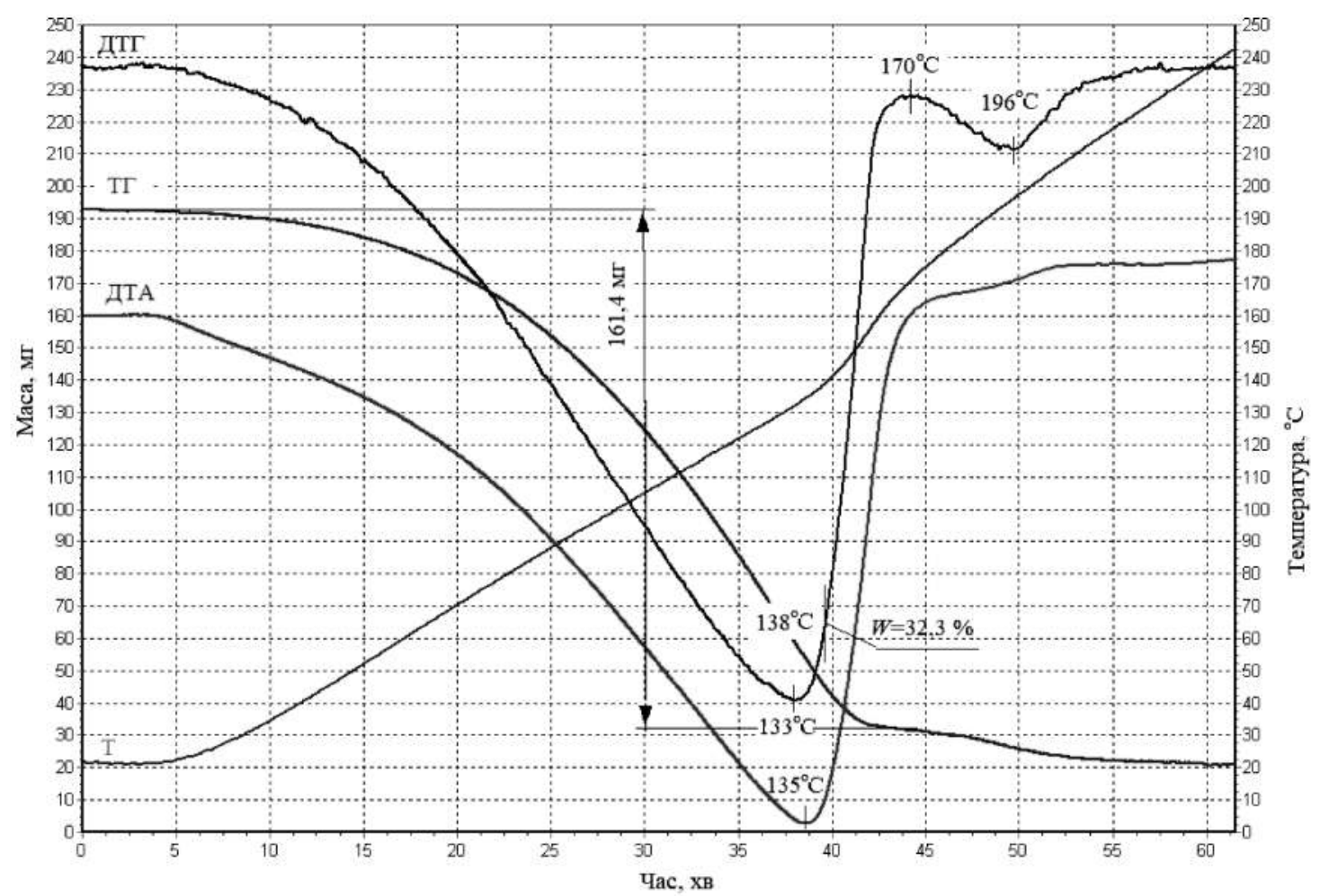

Рис. 3 - Дериватограма паренхімних тканин свіжих яблук сорту Джонатан

Таблиияя 1

Результати аналізу дериватограм свіжих та оброблених парою паренхімних тканин яблук

\begin{tabular}{|c|c|c|c|c|c|c|c|}
\hline $\begin{array}{c}\text { Матеріал } \\
\text { (сорт яблук, } \\
\text { паренхімні тканини) }\end{array}$ & 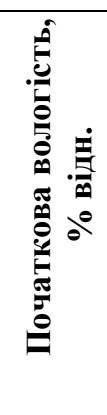 & 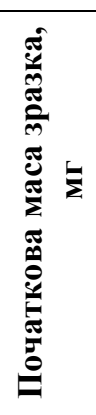 & 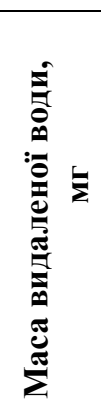 & 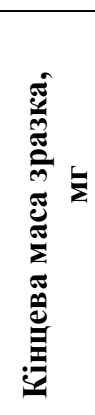 & 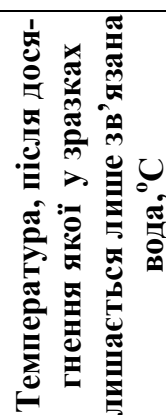 & ט & 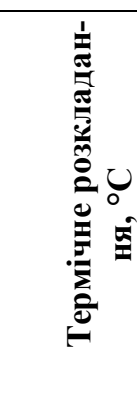 \\
\hline Ренет Симиренко, свіжі & 80,72 & 195 & 157,4 & 25,0 & 139 & 181 & $182 \ldots .249$ \\
\hline Ренет Симиренко, оброблені парою & 85,56 & 224,4 & 192 & 22,8 & 145 & 183 & $184 \ldots 251$ \\
\hline Джонатан, свіжі & 83,63 & 193 & 161,4 & 22,0 & 138 & 170 & $171 \ldots 242$ \\
\hline Джонатан, оброблені парою & 88,22 & 205,4 & 181,2 & 15,4 & 149 & 177 & $178 \ldots 249$ \\
\hline
\end{tabular}

По відношенню до загальної маси видаленої води, зв'язаної води у зразках яблук Ренет Симиренко не менше ніж 13,4 \% та 10 \% у яблуках Джонатан. Відповідно до даних [11] у яблуках міститься $10 \ldots 25 \%$ зв'язаної води. 
Повне зневоднення зразків наступає, коли швидкість зневоднення спадає до нуля. Температура повного зневоднення для яблук сорту Джонатан становить $170{ }^{\circ} \mathrm{C}$, а для яблук Ренет Симиренко $-181{ }^{\circ} \mathrm{C}$.

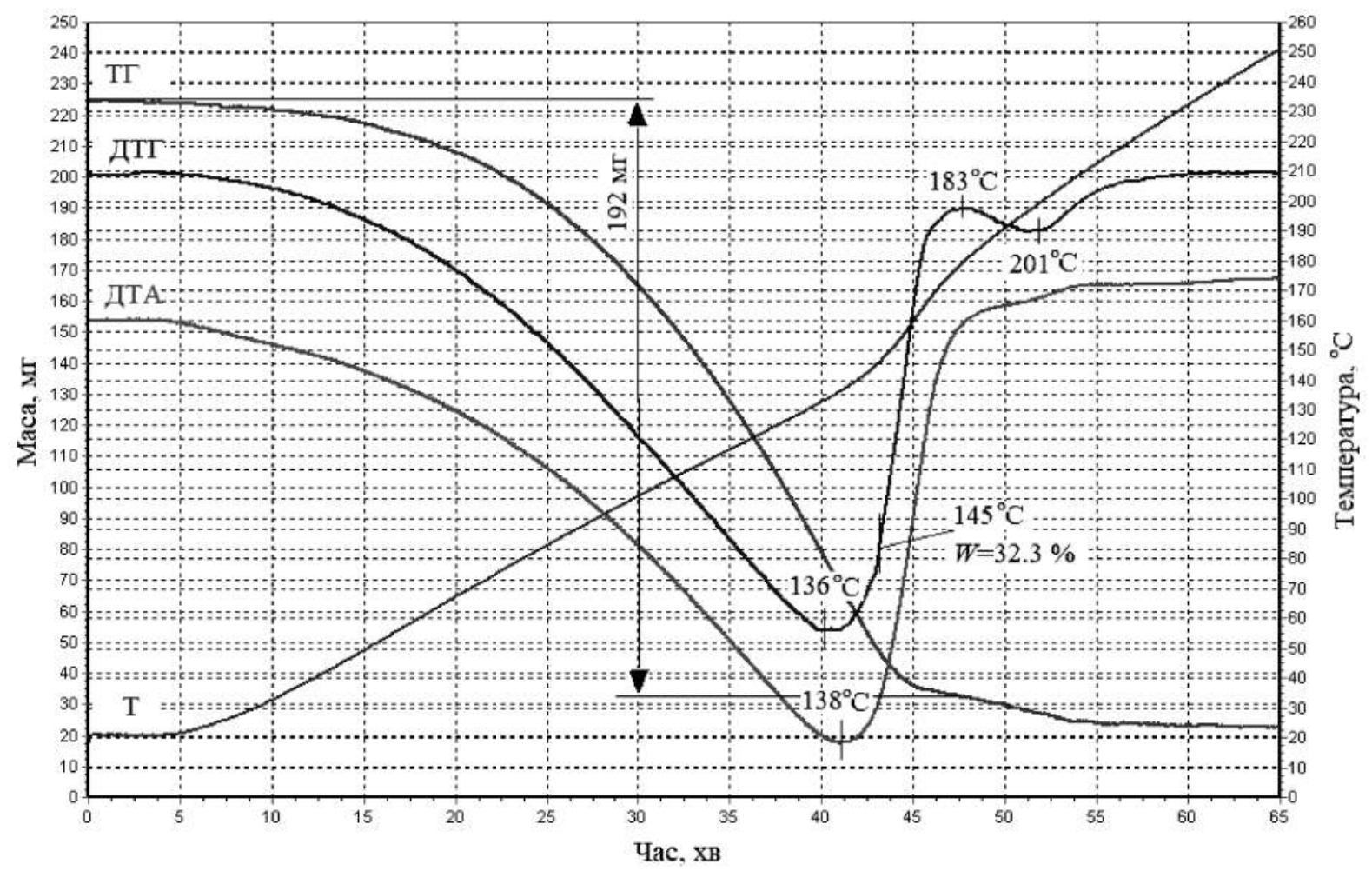

Рис. 4 - Дериватограма оброблених парою паренхімних тканин яблук сорту Ренет Симиренко [8]

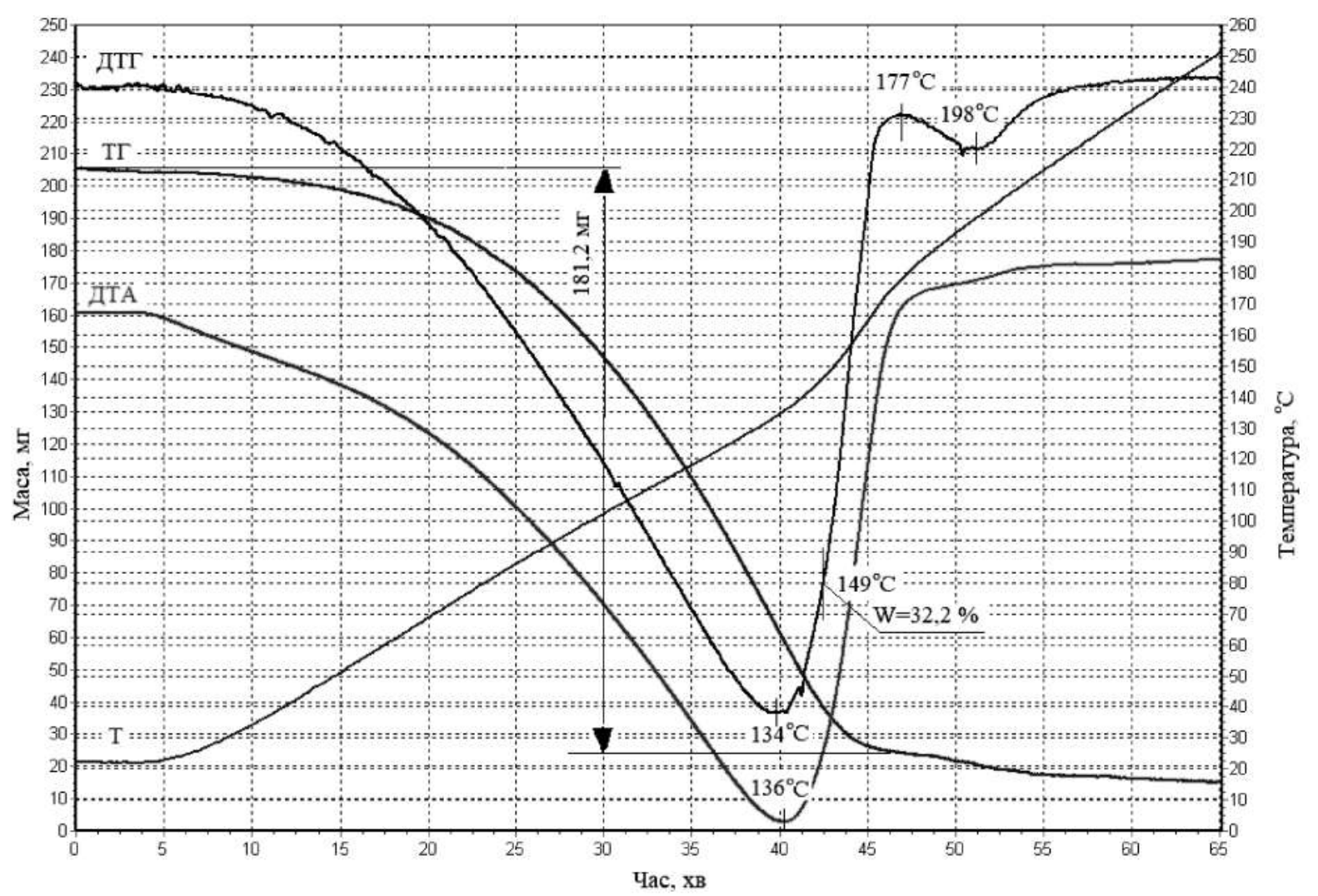

Рис. 5 - Дериватограма оброблених парою паренхімних тканин яблук сорту Джонатан

На кривих дериватограм паренхімних тканин після повного зневоднення в інтервалі температур $182 \ldots 249^{\circ} \mathrm{C}$ (Ренет Симиренко) та $171 \ldots 242{ }^{\circ} \mathrm{C}$ (Джонатан) фіксується втрата маси тканинами 3 максимумом 
швидкості при 205 та $196{ }^{\circ} \mathrm{C}$ відповідно. Як видно з кривих ДТА зміна маси зразків відбувається з виділенням теплоти. По характерним ознакам цей процес ідентифікується як термічне розкладання [10].

3 рисунків 4 та 5 видно, що дериватограми оброблених парою зразків мають такий же характер, як і свіжих яблук. Сумісний аналіз кривих ДТА свіжих та бланшованих парою зразків показав, що їх форми подібні, максимуми піків практично співпадають (температури $137 \ldots 138^{\circ} \mathrm{C}$ для Ренет Симиренко та $135 \ldots 136{ }^{\circ} \mathrm{C}$ для Джонатан).

За результатами аналізу дериватограм оброблених парою паренхімних тканин визначено характерні температури зневоднення в умовах контрольованого нагріву (табл. 1).

Нами зроблене припущення, що гранична вологість, по досягненню якої в зразках залишається лише зв'язана вода, для оброблених парою яблук буде приблизно такою ж, як і для свіжих, тобто $W=32,3$ \%.

По відношенню до загальної маси видаленої води, зв'язаної води у оброблених парою зразках яблук Ренет Симиренко не менше ніж 10,7 \% та 6,3 \% у яблуках Джонатан [8].

Аналізуючи отримані дані можна відмітити, що процес зневоднення в умовах керованого нагріву відбувається залежно від фракційного складу води. При видаленні вільної води, швидкість зневоднення зростає, досягаючи максимальної величини. Для видалення міцно зв'язаної води потрібні вищі витрати енергії, тому швидкість зневоднення знижується [8].

За нашими розрахунками, середня швидкість видалення води у оброблених парою зразках збільшується на 14 \% порівняно із свіжими для яблук Ренет Симиренко та на 5,4 \% для яблук Джонатан. Це може бути пов'язано як з вищою вологістю оброблених парою тканин, так і впливом обробки, яка може призводити до зниження їх водоутримуючої здатності [10], тобто до перерозподілу фракцій води - збільшення кількості вільної води, і відповідно - зменшення зв'язаної.

Отримані за допомогою дериватографії результати підтвердили більший вміст зв'язаної води в свіжих тканинах порівняно з обробленими. Дослідження довели, що у оброблених парою яблук обох сортів зв'язаної води приблизно на 3 \% менше, ніж у свіжих. Це підтверджується середніми значеннями теплоти витраченої на зневоднення.

За методикою, що викладена в [12] було визначено теплоту, яка витрачена на зневоднення зразків. Так середня питома теплота зневоднення свіжих паренхімних тканин яблука сорту Ренет Симиренко в діапазоні температур $25 . .181^{\circ} \mathrm{C}$ (рис. 2) визначена на рівні 2630, а для оброблених парою в діапазоні температур $25 . .183{ }^{\circ} \mathrm{C}$ (рис. 4$)-2500$ кДж/кг [8].

Враховуючи одержані результати, було проведено порівняння кінетики процесу конвективного сушіння в режимі стадійного зневоднення свіжих та оброблених парою зразків яблук сорту Ренет Симиренко (рис. 6).

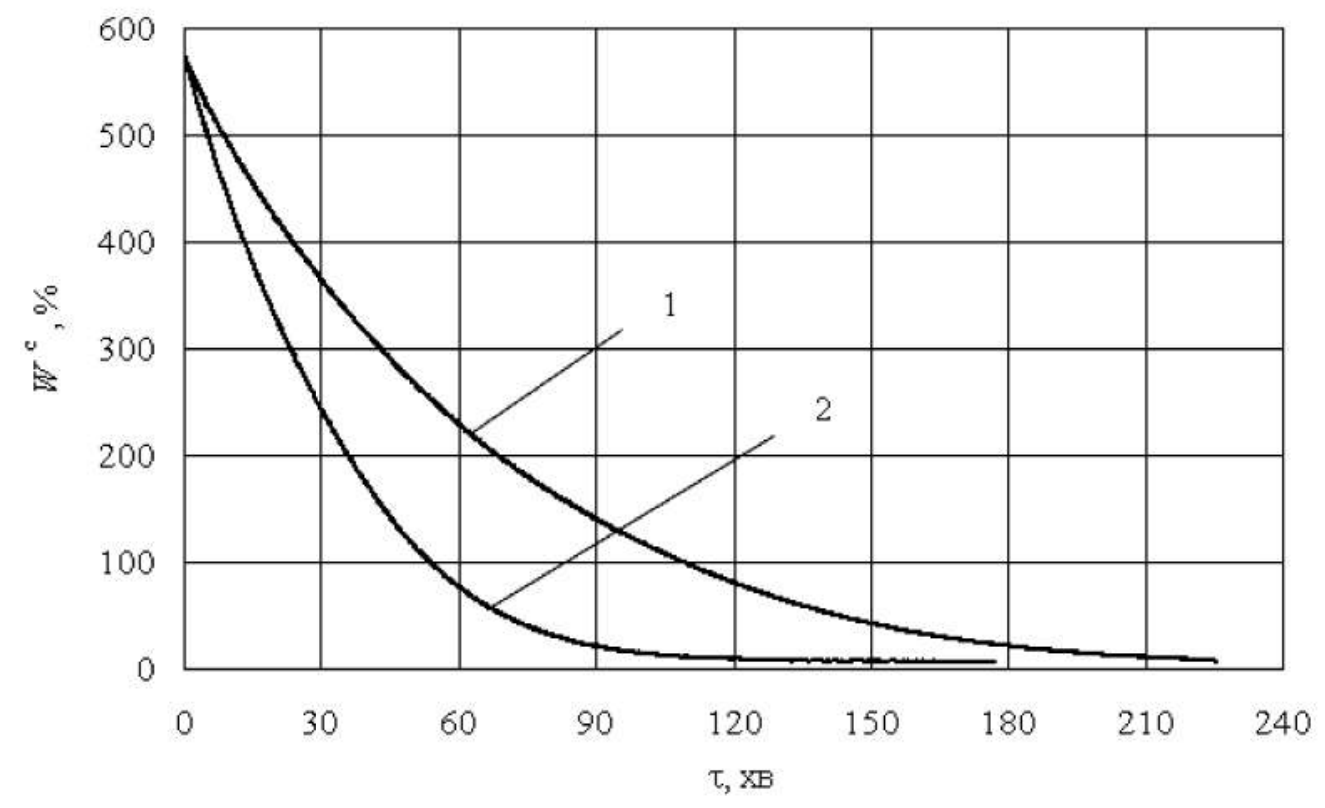

1 - свіжий зразок, 2 - оброблений парою зразок

Рис. 6 - Криві кінетики сушіння зразків яблук сорту Ренет Симиренко

Від кількості зв'язаної води залежить тривалість процесу зневоднення, а отже і енергетична складова процесу. На підставі узагальнення кінетичних закономірностей процесу визначено, що тривалість зневоднення оброблених парою яблук, порівняно із свіжими, скорочується на $20 . .25 \%[13,14]$. Перерозподіл віль- 
ної та зв'язаної води, а також іiі інтенсивніше випаровування відбувається за рахунок руйнування клітинних мембран в результаті термічної обробки тканин. Отримані кінетичні дані корелюють з результатами одержаними термічними методами аналізу.

\section{Висновки}

1. За допомогою методів термічного аналізу визначено температури максимальної швидкості зневоднення, переходу паренхімних тканин яблук в стан, обумовлений вмістом виключно зв'язаної води та температурні інтервали термічного розкладання органічних речовин.

2. Вперше для яблук сорту Ренет Симиренко показано, що у оброблених парою зразках паренхімних тканин через руйнування клітинних мембран відбувається перерозподіл вільної та зв'язаної води, частина зв'язаної води переходить у вільну, що підтверджується значеннями середньої питомої теплоти зневоднення.

3. На підставі узагальнення кінетичних закономірностей процесу сушіння визначено, що тривалість зневоднення оброблених парою яблук, порівняно з свіжими, скорочується на $20 . .25 \%$.

Дослідження підтверджують доцільність тепловологісної обробки паренхімних тканин сировини перед сушінням з метою інтенсифікації зневоднення та зменшення енергетичних витрат. Отримані результати можна використовувати при виборі виду попередньої обробки яблук та у теплових розрахунках процесу зневоднення.

\section{References}

1. Skurihina, I. M., Volgareva, M. N. (1987). Himicheskiy sostav pischevyih produktov [Chemical composition of food products]: sprav. tablitsyi. Kn. 2. Moskva: Agropromizdat (in Russian).

2. Korobka, S.V. (2016). Obgruntuvannia parametriv ta rezhymiv roboty heliosusharky fruktiv [Foundation of parameters and operating modes of the fruit solar dryer]: dys....kand. tekhn. nauk: 05.05.11. Lviv: Lvivskyi natsionalnyi ahrarnyi universytet (in Ukrainian).

3. Mikhailik, V. A., Dmitrenko, N. V., Snezhkin, Yu. F. (2019). Investigation of the Influence of Hydration on the Heat of Evaporation of Water From Sucrose Solutions. Journal of Engineering Physics and Thermophysics, 92 (4), 916-922.

4. Mihaylik, V.A., Snezhkin, Yu.F., Belinskiy, V.T. (2005). Primenenie derivatografa dlya issledovaniya vliyaniya predvaritelnoy termicheskoy obrabotki na kinetiku sushki rastitelnogo syirya [Application of a derivatograph to study the effect of pre-heat treatment on the kinetics of drying plant raw materials]. Problemyi promyishlennoy teplotehniki: sbornik tezisov dokladov IV Mezhdunarodnoy konferentsii. Kiev, 26-30 (in Russian).

5. Rubanka, K. V., Terletska, V. A., Zinchenko, I. M. (2013). Doslidzhennia zminy form zviazku volohy pid chas sushinnia ekstraktu chaiu zelenoho [Investigation of changes in moisture binding forms during drying of green tea extract]. Khranenye y pererabotka zerna, 11 (176), 46-48 (in Ukrainian).

6. Wesołowski, M., Konieczyński, P., Ulewicz, B. (2000). Influence of the elemental composition of medicinal fruits on the results of their thermal analysis. Journal of Thermal Analysis and Calorimetry, 60, $299-304$. https://doi.org/10.1023/A:1010142517579.

7. Derivatograf sistemyi Paulik F., Paulik Y., Erdei L. (1974). Teoreticheskie osnovyi. Vengerskiy opticheskiy zavod. Budapesht, 146.

8. Husarova, O.V., Mykhailyk, V.A. (2019). Deryvatohrafichnyi analiz form zviazku vody v yablukakh. Resursoenerhozberihaiuchi tekhnolohii ta obladnannia [Derivatographic analysis of water bond forms in apples. Resource-saving technologies and equipment]: zbirnyk tez dopovidei XVI mizhnarodnoi naukovopraktychnoi konferentsii studentiv, aspirantiv i molodykh vchenykh. (Kyiv, 22 - 23 kvitnia 2019). Kyiv, 14-16 (in Ukrainian).

9. Mikhailik, V. A., Dmitrenko, N. V., Snezhkin, Yu. F. (2014). Change in the specific heat capacity of parenchymal tissues of apples due to dehydration. Journal of Engineering Physics and Thermophysics, 87 (1), 45-50.

10. Mihaylik, V.A., Dmitrenko, N.V., Mihaylik, T.A. (2007). Vliyanie termicheskogo vozdeystviya na sostoyanie vodyi $\mathrm{v}$ rastitelnyih tkanyah [The effect of thermal exposure on the state of water in plant tissues]. Promyishlennaya teplotehnika, 29 (7), 212-217 (in Russian).

11. Yuzina, A.V., Makarova, N.V. (2009). Napitki na osnove yablochnogo soka [Drinks based on apple juice]. Izvestiya vuzov. Pischevaya tehnologiya, 4, 5-7.

12. Mykhailyk, V.A., Sniezhkin, Yu.F., Korinchevska, T.V., Hornikov, Yu.I. (2015). Vplyv rezhymu konvektyvnoho sushinnia na krystalichnist poroshkiv z yabluk ta tsukrovoho buriaku [Effect of convective drying mode on the crystallinity of apple and sugar beet powders]. Promyishlennaya teplotehnika, 37 (5), 2337.

13. Shapar, R.O., Husarova, O.V. (2019). Vplyv teplovolohoi obrobky na kinetyku sushinnia pektynovmisnykh materialiv [Influence of heat and moisture treatment on the drying kinetics of pectin-containing materials]. Scientific Works, 83 (1), 62-66. https://doi.org/10.15673/swonaft.v83i1.1419.

14. Husarova, O., Shapar, R., Sorokova, N. (2020). Intensification of heat and mass transfer during the convective 
drying of apple to low final moisture: in monograph Theoretical and practical aspects of the development of the european research area. Riga, Latvia: Publishing House "Baltija Publishing", 191 - 211. https://doi.org/10.30525/978-9934-588-53-2-52.

\title{
INFLUENCE OF STEAM TREATMENT OF APPLES ON SPECIFIC HEAT OF DEHYDRATION
}

\author{
Husarova O.V., Mykhailik V.A., Shapar R.O. \\ Institute of Engineering Thermophysics of the National Academy of Sciences of Ukraine, \\ Kyiv, Ukraine
}

The process of removing water from apples was studied by TG and DTA methods for more reasonable identification of possibilities of intensification of drying and deeper understanding of the processes that occur during dehydration of apples.

Fresh and steamed samples of parenchymal tissues of apples of Renet Simirenko and Jonathan varieties were used as objects of the study. The study was performed in a $Q-1000$ derivatograph in the range of $25 \ldots 250^{\circ} \mathrm{C}$ at a heating rate of $3.6 \mathrm{~K} / \mathrm{min}$. Apples dehydration was carried out by the method of convective drying to a residual moisture content of $6 \%$.

The temperatures of the maximum rate of dehydration, the transition of parenchymal tissues to a state due to the content of exclusively bound water, and temperature intervals of thermal decomposition of organic matter were determined.

In the paper it is noted that the course of the dehydration process under controlled heating depends on the state of the water. The average rate of water removal from steam treated fabrics in Renet Simirenko apples is $14 \%$ higher than in fresh ones.

First for apples Reinette Simirenko shown that couple treated samples due to the destruction of cell membranes redistribution of free and bound water, some bound water moved in the free, as evidenced by the average values of the specific heat of dehydration that for fresh apples Reinette Simirenko in the temperature range of $25 \ldots 181{ }^{\circ} \mathrm{C}$ is defined at the level of 2630, and for steam treated in the temperature range of $25 \ldots 183{ }^{\circ} \mathrm{C}-2500 \mathrm{~kJ} / \mathrm{kg}$. Steamed apples of both types of bound water are $\sim 3 \%$ less than fresh ones.

Studies confirm the feasibility of heat and moisture treatment of parenchymal tissues of raw materials before drying in order to intensify dehydration and reduce energy costs. The obtained results can be used when choosing the mode of preliminary heat and moisture treatment of apples and in thermal calculations of the dehydration process.

Keywords: derivatography, drying, apples, steam treatment, average specific heat of dehydration, free and bound water.

\section{Список використаної літератури}

1. Скурихина, И. М., Волгарева, М. Н. Химический состав пищевых продуктов: справ. таблицы. Кн. 2. Москва: Агропромиздат, 1987. 360 с.

2. Коробка, С.В. Обгрунтування параметрів та режимів роботи геліосушарки фруктів: дис....канд. техн. наук: 05.05.11. Львів: Львівський національний аграрний університет, 2016. 295 с.

3. Mikhailik, V. A., Dmitrenko, N. V., Snezhkin, Yu. F. Investigation of the Influence of Hydration on the Heat of Evaporation of Water From Sucrose Solutions. Journal of Engineering Physics and Thermophysics, 2019. Vol. 92, No 4. pp. 916-922.

4. Михайлик, В.А., Снежкин, Ю.Ф., Белинский, В.Т. Применение дериватографа для исследования влияния предварительной термической обработки на кинетику сушки растительного сырья. Проблемы промышленной теплотехники: сборник тезисов докладов IV Международной конференции. Киев, 2005. С. 26-30.

5. Рубанка, К. В., Терлецька, В. А., Зінченко, І. М. Дослідження зміни форм зв'язку вологи під час сушіння екстракту чаю зеленого. Хранение и переработка зерна. 2013 . № 11 (176). С. 46 - 48.

6. Wesołowski, M., Konieczyński, P., Ulewicz, B. Influence of the elemental composition of medicinal fruits on the results of their thermal analysis. Journal of Thermal Analysis and Calorimetry. 2000. № 60, pp. $299-304$. https://doi.org/10.1023/A:1010142517579.

7. Дериватограф системы Паулик Ф., Паулик Й., Эрдеи Л. Теоретические основы. Венгерский оптический завод. Будапешт, 1974. 146 с.

8. Гусарова, О.В., Михайлик, В.А. Дериватографічний аналіз форм зв'язку води в яблуках. Ресурсоенергозберігаючі технології та обладнання: збірник тез доповідей XVI міжнародної науково-практичної конференції студентів, аспірантів і молодих вчених. (Київ, 22 - 23 квітня 2019). Київ, 2019. 
C. $14-16$.

9. Mikhailik, V. A., Dmitrenko, N. V., Snezhkin, Yu. F. Change in the specific heat capacity of parenchymal tissues of apples due to dehydration. Journal of Engineering Physics and Thermophysics, 2014. Vol. 87, No. 1. P. $45-50$.

10. Михайлик, В.А., Дмитренко, Н.В., Михайлик, Т.А. Влияние термического воздействия на состояние воды в растительных тканях. Промышленная теплотехника, 2007. Т. 29, № 7. С. 212 - 217.

11. Юзина, А.В., Макарова, Н.В. Напитки на основе яблочного сока. Известия вузов. Пищевая технология. 2009. № 4. C. $5-7$.

12. Михайлик, В.А., Снєжкін, Ю.Ф., Корінчевська, Т.В., Горніков, Ю.І. Вплив режиму конвективного сушіння на кристалічність порошків з яблук та цукрового буряку. Промышленная теплотехника. 2015. Т. 37, № 5. C. $23-37$.

13. Шапар, Р.О., Гусарова, О.В. Вплив тепловологої обробки на кінетику сушіння пектиновмісних матеріалів. Наукові праці ОНАХТ. Одеса, 2019. Вип. 83. Т. $1 . \quad$ С. 62 - 66. https://doi.org/10.15673/swonaft.v83i1.1419.

14. Husarova, O., Shapar, R., Sorokova, N. Intensification of heat and mass transfer during the convective drying of apple to low final moisture: in monograph Theoretical and practical aspects of the development of the european research area. Riga, Latvia: Publishing House "Baltija Publishing", 2020. P. 191 - 211. https://doi.org/10.30525/978-9934-588-53-2-52.

Отримано в редакцію 21.03.2021

Прийнято до друку 23.06.2021
Received 21.03.2021

Approved 23.06.2021 